\title{
A MECHATRONIKA ALKALMAZÁSA A BÁNYAGÉPEK TERVEZÉSÉBEN
}

\section{IMPLEMENTING MECHATRONICS IN MINING EQUIPMENT DESIGN}

\author{
András József ${ }^{1}$, Kovács József ${ }^{2}$ \\ Petrozsényi Egyetem, Gépész- és Villamosmérnöki Kar, Gépész-, Ipari és Szállitás- \\ mérnöki Tanszék, Cím: 332006, Románia, Petrozsény, Universităţii, 20. \\ Iosif.andras@gmail.com \\ ${ }^{2}$ kovacsi@mail.com
}

\begin{abstract}
The traditional design of mining machinery manages separately the structural and functional parts of the design object (mechanical, electrical, hydraulic and control units). The mechatronics, as a design philosophy may offer an innovative approach in the design of plant and equipment used in open-pit or underground mining. The multi-domain nature of these machines, may lead, in a traditional design approach, to the difficulty of optimal harmonization of constructive - functional parts belonging to separate domains. The present paper examines the theoretical and conceptual aspects of the question how engineering design methods, inspired by mechatronics can be used in the development of mining equipment.
\end{abstract}

Keywords: mining equipment, mechatronics, design, development, innovation.

\section{Összefoglalás}

A bányagépek hagyományos tervezése külön-külön kezeli a tervezés alanyának szerkezeti és funkcionális részeit (mechanikus, villamossági, hidraulikus és vezérlő egységeit). A mechatronika mint tervezési filozófia innovatív megközelítést ajánlhat a külszíni vagy mélymüveléses bányászatban alkalmazott gépek és berendezések rendszeres tervezésében. Ezen gépek többtartományos jellege, a hagyományos tervezésben arra vezethet, hogy a külön tartományokhoz tartozó szerkezeti - funkcionális részeinek optimális összehangolása nem lehetséges. A jelen dolgozat annak az elgondolásnak az elméleti és fogalmi vonatkozásait vizsgálja, hogy a mechatronika által inspirált mérnöki tervezés módszerei hogyan alkalmazhatók a banyagépek fejlesztésében. Ismert tény, hogy a bányászatban alkalmazott gépek és berendezések szerkezeti komplexitása, azok müködési környezetének változatossága és agreszszivitása késést idézett elő a korszerü tudomány vívmányai által serkentett technológiai haladás terén. Ennek ellenére az utóbbi két évtizedben, az általános technológiai haladás befolyásának köszönhetően, a bányagépek és berendezések példátlan kifinomultságot és komplexitást értek el. Az informatika, a szenzorok, a meghajtó egységek terén elért haladás a vezérlö és ellenőrző szerkezetek terén is elörelépést gerjesztett, áthidalva a mechanikus szerkezetek fogalmi elavultságát. Ez, az általános technológia területén létrejött haladás új módszereket követelt a bányagépek tervezése és fejlesztése vonatkozásában is.

Kulcsszavak: bányagépek, mechatronika, tervezés, fejlesztés, innováció 


\section{A bányagépek fejlődésének sajá- tosságai}

A bányászat, az emberiség történetében, hosszú ideig jelentős hatást gyakorolt az általános társadalmi és gazdasági fejlődésre. Több olyan korszakalkotó technológiai újítás, mint például a gőzgép vagy a szivattyúk a bányászat aranykorához kötődnek.

A következő korszakban a bányászat mint nyersanyag-szolgáltató, a technológia fejlődésének eredményeit elsőnek alkalmazta, mint például a sürített levegö, villamosmotor, hidraulika stb., serkentve ezek fejlődését.

Függetlenül a napjainkban észlelhető relatív stagnálástól, melyet a bányászatra ható súlyos gazdasági, pénzügyi és környezetvédelmi korlátozások okoztak, a bányászat továbbra is alapvető eleme minden jövőre vonatkozó elemzésnek, ami az energiaforrások és az alapvető nyersanyagokkal való ellátást illeti.

Viszonylagos pangásokat és evolúciókat hozó, egymást követő fejlödési időszakok után a bányászatban alkalmazott kulcsfontosságú technológiák, berende-zések és müszaki megoldások a harmadik évezred küszöbén elértek egy bizonyos fokú érettséget, amely egy forradalmi ugrás kezdetének indító elemét jelentette, melynek hatása napjainkban is érzékelhető.

A gyártási technológiáknak, a jelenlegi technológiai fejlödés hajtóelemeinek, mint az elektronika, finommechanika, automatikus vezérlés és a számítástechnika példátlan haladása, melynek eredményeit egyszerübben és gazdaságilag motiváltab-ban lehetett beilleszteni más iparágakban, mint a bányászatban, oda vezetett, hogy a bányagépek fejlődésében lemaradás jött létre a technológiai fejlődés élvonalában lévő ipari területekhez viszonyítva.

Mivelhogy a bányászatban alkalmazott technológiák és berendezések fejlődése lassabb ütemben haladt más ipari ágakhoz vi- szonyítva, ezek tervezési-fejlesztési módszerei is késve nyertek tudományos megalapozást.

Mindezek a problémák jelennek meg ma a bányászat vonatkozásában nem csupán a fejlődő országokban, amelyek a hagyományos alapvető nyersanyagok világméretü szolgáltatói, hanem a jól fejlesztett gazdasággal rendelkező országokban is.

Ahhoz, hogy e jelenségek túlszárnyalásához életképes megoldások szülessenek, az eddigi technológiai fejlödés ismerete szükséges.

Ahogyan ezt Klaus Spies [5] német feltaláló és ipartörténeti szakember kimutatta, a bányászatban alkalmazott technológia fejlesztése mindig a kreativitás és a hagyományos megoldások szimbiózisából született, mivelhogy az innováció a bányászati tevékenység terén külön sajátosságokkal rendelkezik.

Egyrészt bonyolult, mivel sokdimenziójú (a bánya életciklus folyamatának több szakaszára vonatkozik, úgymint a feltárás, kitermelés és feldolgozás, erőforrásgazdálkodás, újrahasznosítás, bányabezárás és környezet-helyreállítás), másrészt maga a kitermelés, bár egyszerü alapmüveleteken alapszik, célspecifikus gépeket és berendezéseket igényel.

Tudva azt, hogy a bányászati technológia három alapvető müveleten alapul, éspedig a jövesztés, rakodás-szállítás és üregbiztosítás, ezen alapmüveletek gépesítése néha egymástól függetlenül, de egymást befolyásolva fejlődött.

Ezzel kapcsolatosan az alábbi következtetéseket lehet levonni:

- A technológiai fejlődés meghatározó eleme a kőzet jövesztése, tehát az ezt végző gép vagy technológia.

- Kiindulva egy bizonyos pillanattól, a fejlődés, illetve az elörelépés fontos tényezője a jövesztés gépesítése által elért magasabb termelékenység, nagyobb kőzethozam, melynek következménye a további müveletek gépesí- 
tésének/korszerüsítésének szükségessége.

Érdemes megfigyelni, hogy a bányászati technológiák fejlődésének az a sajátossága, hogy egy komponens ugrásszerü újítása a másik két komponenst is újításra kényszeríti, ami ciklikusan végül ahhoz vezet, hogy egy teljesen új technológia alakul ki.

A banyagépek egy másik sajátossága az, hogy a gépesítés követi a technológiai eljárást, ahhoz illeszkedik. A teljesítmény növelése méret- és súlynövelést igényel, a mozgó munkahely a gép mobilitását helyezi a fontos adottságok közé, s a 4 müvelet 4 végrehajtó eszközt igényel, tehát a szakosítás és univerzalitás között kell kompromiszszumot elérni.

\section{Alkalmazási példa}

Annak érdekében, hogy kiemeljük a több-tartományi elemzés fontosságát a mechatronika elméletein alapozott bányagépek és berendezések tervezésének megközelítésében, bemutatjuk az (egyébként szegény) irodalomból a következő helyzeti példát $[2,3,4]$.

A kiindulási pont egy autonóm rakodószállító berendezés (LHD) egy, a rakodás folyamatát ábrázoló sémája (1. ábra).
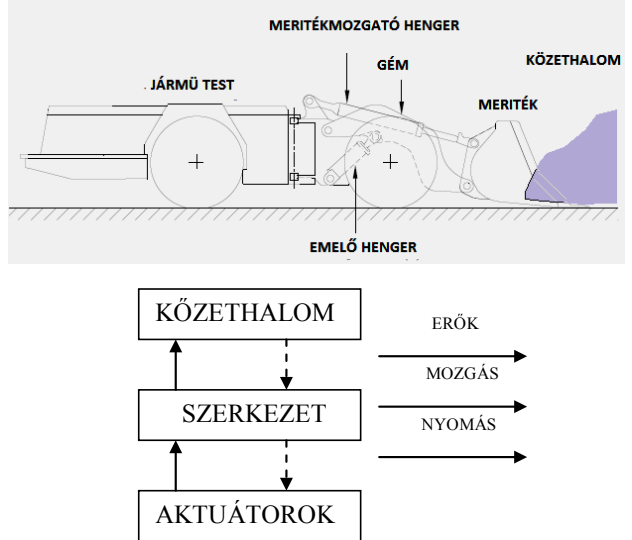

1. ábra. Az LHD rakodógép (felsö) és a rakodás sémája (alsó) [3]
Feltételezzük, hogy a rakodógépet három fizikai rendszerben lehet lebontani, nevezetesen: (1) a mechanikai szerkezet (gém, meriték és jármü), (2) a müködtető szerkezet (hidraulikus emelö és mozgató hengerek és esetleg a jármü vonóereje, amelyek kölcsönösen hatnak a mechanikai szerkezettel) és (3) a jövesztett kőzet-halom, amellyel a fizikai szerkezet kölcsönhatása közben a rakodási müvelet végeztetik.

Érdemes megjegyezni, hogy a hengerekben keletkező és változó nyomások mérési adatokat tartalmaznak nem csupán a müködtető bemeneti jelekről, hanem információt rejtenek a gép mechanikai szerkezetének mozgásairól és a kőzethalommal való interakció állapotáról, amint a kísérleti megfigyelések kimutatták.

A mechatronikai szemlélet fontossága abban ál, hogy a három fó áramlatot, amely egy komplex berendezés alkotó részein keresztül áramlik, egybevéve, összekapcsolva veszi figyelembe, éspedig anyag, energia és információ. Ezt a 2. ábra szemlélteti [2].

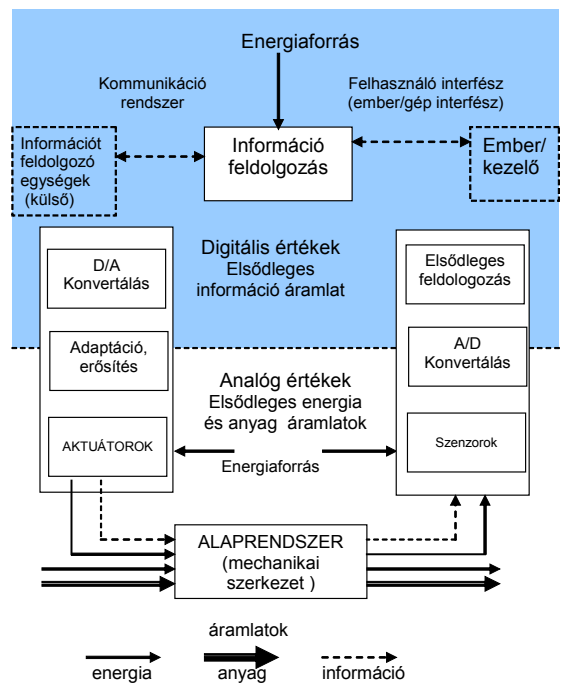

2. ábra. A mechatronikus rendszer elvi szerkezete [2] 
A releváns fizikai értékeket szenzorok mérik, ezek alapján az igényelt feladatok végrehajtását, irányító jeleket gerjesztik.

$\mathrm{Az}$ analóg értékeket digitálisra konvertálják és bizonyos élőfeldolgozás után egy digitális adatfeldolgozó egységnek pl. mikrokontrollernek továbbítják.

Az adatfeldolgozó egység meghatározza a szükséges változásokat az alaprendszerben, tekintettel a mért adatokra, a felhasználó igényeit (ember-gép interfész), és egyébb az adatfeldolgozó rendszer által szolgáltatott információkat nyújt (kommunikációrendszer).

Digitális/analóg konverzió folytán az energiaáramlat módosításával az aktuátorok megfelelő változásokat eszközölnek az alaprendszer müködésében.

\section{Következtetések}

Ma a bányászat olyan helyzetben van, amikor egy fontos technológiai ugrás szükségességét jelző tüneteket nem lehet figyelmen kívül hagyni.

A mechatronika által szolgáltatott megközelítés az intelligens gépek tudományaként, a komplex elektromechanikus rendszerek tervezésébe az utóbbi időben beágyazódott fejlesztési filozófia új utakat nyithat müködési, fogalmi és eljárási szempontból egy új berendezésgeneráció megvalósításához a bányaipar számára.

A mechatronika - egy új feltörekvő határtudomány - képes új használhatósági és teljesítményi minőséget nyújtani a bányászatban alkalmazott gépeknek és berendezéseknek, a tervezők gondolkodásmódját is befolyásolva, azzal, hogy az irányító, ellenőrzési, felügyeleti és szabályozási rendszerek nemcsak „hozzáadott”, különálló funkcionális blokkok, hanem be vannak ágyazva mint az egységes rendszeralkotó részei.

Ugyanakkor a gépet egységesen tervezik meg mint egész amelyben a mechanikus, hidraulikus, elektromos és informatikai alrendszerek integrált elemekként vannak beépítve.

\section{Szakirodalmi hivatkozások}

[1] Andras, A.: Study related to the improvement of mining equipment design methods. Ph.D. Thesis, University of Petroșani, 2006.

[2] Gausemeier, J.: From Mechatronics to SelfOptimization, 20th International Congress CAD-FEM Users' Meeting, 2002.

[3] Marshall, J.A.: Towards Autonomous Excavation of Fragmented Rock: Experiments, Modelling, Identification and Control. M.Sc. thesis, Queen's University, 2001.

[4] Mrozek, Z.: Computer Aided Design of Mechatronic Systems. Int. J. Appl. Math. Computer Sci., 2003, Vol. 13, No. 2, 255-267.

[5] Spies, K.: Methodical Development Process For Improvement of Methods and Machinery in Mining. Mining Science \& Technology: Proceedings of the International Symposium on Mining Technology and Science, August 1985. 